Print ISSN: 2288-4637 / Online ISSN 2288-4645

doi:10.13106/jafeb.2018.vol5.no4.9

\title{
Influence of Global versus Local Rating Agencies to Japanese Financial Firms*
}

\author{
Seung Hun Han ${ }^{1}$, Walter J. Reinhart ${ }^{2}$, Yoon S. Shin ${ }^{3}$ \\ Received: August 10, 2018 Revised: September 28, 2018 Accepted: September 30, 2018
}

\begin{abstract}
Global rating agencies, such as Moody's and S\&P, have assigned credit ratings to corporate bonds issued by Japanese firms since 1980 s. Local Japanese rating agencies, such as R\&I and JCR, have more market share than the global raters. We examine the yield spreads of 1,050 yen-denominated corporate bonds issued by financial firms in Japan from 1998 to 2014 and find no evidence that bonds rated by at least one global agency are associated with a significant reduction in the cost of debt as compared to those rated by only local rating agencies. Unlike non-financial firms, the reputation effect of global rating agencies does not exist for Japanese financial firms. We also observe that firms with less information asymmetry are more likely to acquire ratings from Moody's or S\&P. Additionally, the firm's financial profile does not affect its choice to seek out ratings from global raters. Our findings are contradictory to those by Han, Pagano, and Shin (2012), who employ bonds issued by non-financial firms in Japan. Our conjecture is that the asymmetric nature of financial firms makes investors less likely to depend on a credit risk assessment by rating agencies in determining the yields of new bonds.
\end{abstract}

Keywords: Rating Agency, Credit Ratings, Japanese Capital Markets, Cost of Debt, Banks, Financial Firms.

JEL Classification Code: G10, G14, G15.

\section{Introduction}

The influence of global rating agencies such as Moody's and S\&P is so substantial that they control about $80 \%$ of the global credit ratings market (Wall Street Journal, 2003). ${ }^{i}$ There is evidence regarding the influence of global and local rating agencies in local financial markets. ${ }^{i} \mathrm{Li}$, Shin, and

* This study was funded by the Travelers Research Grant from The Sellinger School of Business and Management, Loyola University Maryland, USA.

1 First Author. Associate Professor, School of Business and Technology Management, College of Business, Korea Advanced Institute of Science and Technology (KAIST), South Korea,

E-mail: synosia@kaist.ac.kr

2 Second Author. Professor, Department of Finance, The Sellinger School of Business and Management, Loyola University, Maryland, USA, E-mail: reinhart@loyola.edu

3 Corresponding Author. Associate Professor, Department of Finance, The Sellinger School of Business and Management, Loyola University, Maryland, USA [Postal Address: 4501 North Charles Street, Baltimore, MD 21210, USA]

Tel. 410-617-2869, E-mail: yshin@loyola.edu
Moore (2006) find that the stock prices of Japanese firms react more strongly to rating downgrades by global rating agencies than by two Japanese rating agencies. Shin and Moore (2003) shows that the ratings of Japanese firms by global agencies are lower than those assigned by Japanese agencies. Using bonds issued by non-financial Japanese firms from 1998 to 2009, Han, Pagano, and Shin (2012) find that bonds rated by global agencies such as Moody's and S\&P are issued at significantly lower yields than those rated by Japanese rating agencies such as R\&I and JCR. The lower yields exist even though global agencies assign lower ratings than the Japanese agencies. Han et al. (2012) also determine that, during the 2007-2009 financial crisis, the yields on Japanese bonds rated by Moody's or S\&P increased significantly and fully negated the advantage of obtaining a bond rating from a global rater. This finding suggests that the reputation of global rating agencies was tarnished during the financial crisis period (April 24, 2007 to March 31, 2009).

We examine the yield spreads of 1,050 new yendenominated corporate bonds issued by financial firms in Japan such as commercial banks, insurance companies, 
and investment banks from 1998 to 2014 and find no evidence that bonds rated by at least one global agency are associated with a significant reduction in the cost of debt compared to those rated by only local Japanese rating agencies. Unlike non-financial firms, the reputation effect of global rating agencies does not exist for Japanese financial firms. We also observe that firms with less information asymmetry and higher growth potential are more likely to acquire ratings from Moody's or S\&P. Additionally, the firm's financial profile does not affect its choice to seek out ratings from global raters. Our findings are contradictory to those by Han et al. (2012), who employ bonds issued by nonfinancial firms in Japan from 1998 to 2009.

Our conjecture is that the asymmetric nature of financial firms makes investors less likely to depend on a credit risk assessment by rating agencies in determining the yields of new bonds. According to Fabozzi (2007), ${ }^{\text {iii }}$ financial firms pay different yields compared to non-financial firms when they issue bonds. Morgan (2002) finds that banks and insurance companies are more opaque than non-financial firms, and S\&P and Moody's assign more split ratings to financial firms due to greater uncertainty inherent in the assets of banks or insurance companies. Packer and Tarashev (2011) argues that assessing the credit risk of banks is very challenging because banks in financial distress are more likely to be bailed out by the government than non-financial firms, and the stock returns of banks are more volatile than those of non-financials due to higher debt ratio and asset opaqueness. Packer and Tarashev (2011) also state that rating agencies such as S\&P, Moody's, and Fitch issue two types of credit ratings to banks because of the difficulty in the credit risk assessment. ${ }^{\text {iv }}$ Furthermore, the R\&I (2017) report shows that the historic default rates of banks in Japan are much lower than those of non-financial Japanese firms. According to Okabe (2009), the Ministry of Finance in Japan, the regulatory authority, monitors banks and rescues troubled banks if necessary. Hence, credit ratings are less important to financial firms compared to non-financial firms in Japan.

We report that the absolute rating differences of the financial firms in our study are greater than those of the nonfinancial firms in the research of Han et al. (2012). Results also show that local rating agencies as well as global rating agencies incorporate the asset opaqueness of financial firms into their ratings. In addition, our findings show that the credit ratings of financial firms are less important than those of non-financial firms in determining the cost of debt. We claim that investors do not depend on the reputation of global rating agencies because of the greater asymmetric information inherent in the credit ratings of financial firms.

Japan has the second largest bond markets in the world, and global rating agencies, such as Moody's and S\&P, have assigned credit ratings to corporate bonds issued by Japanese firms since 1980s. Local Japanese rating agencies, such as R\&I and JCR, have more market share than the global rating agencies. The two local rating agencies such as R\&I and JCR were designated as the Nationally Recognized Statistical Rating Organizations (NRSROs) in 2007 by the U.S. Securities and Exchange Commission (SEC). ${ }^{\vee}$ The SEC has certified Moody's, S\&P, and Fitch as the NRSROs since 1975. The SEC has issued NRSRO certifications to ten rating agencies in the world as of 2018. Credit ratings by the NRSROs are used as a benchmark for investment decisions (Bolton, Freixas, \& Shapiro, 2012) and regulations (Kisgen \& Strahan, 2010). For instance, the SEC also allows commercial banks to use credit ratings assigned by NRSROs in calculating their capital requirements.

In contrast, credit ratings on Japanese firms by the NRSROs are not subject to the regulatory rules specified by the SEC. This means that when Japanese firms issue yendenominated bonds, they do not need to obtain ratings from the NRSRO agencies because these bonds are not regulated by the SEC. Additionally, Yamori, Nishigaki, and Asai (2006) explain that Japanese firms can issue bonds without ratings and there are no regulations or investment policies that require the use of ratings by Japanese institutional investors. Hence, we assume the SEC regulations do not affect the bond yields in Japan.

Our research is different from that of Han et al. (2012) in the following perspectives. First, we expand the study of Han et al. (2012) with regard to new bonds issued by firms in Japan by focusing on financial firms while they examined non-financial firms (such as industrial firms, utilities, and transportation). Second, the sample period is extended from 1998 to 2014, while the sample period of Han et al. (2012) is from 1998 to 2009. Third, we compare the rating methodology of financial firms between the global and local rating agencies, and examine whether rating agencies incorporate the asymmetric information of financial firms into their ratings. Our research is composed of the following sections: Section 2 reviews relevant literature, Section 3 describes hypotheses and research methods, Section 4 presents data and descriptive statistics, Section 5 reports empirical results, and Section 6 provides robustness checks. Finally, Section 7 concludes our study.

\section{Literature Review}

There are several studies investigating the reputation effect of rating agencies. For example, Shin and Moore (2008) examine the NRSRO designation of Canada's Dominion Bond Rating Service (DRBS) and find that the 
NRSRO designation alone does not establish a rating agency reputation. The findings of Shin and Moore (2008) imply that investors value the ratings of global agencies because Moody's or S\&P may possess special skills in assessing credit risk. Sufi (2009) reports that firms acquiring syndicated bank loan ratings from S\&P or Moody's improve the availability of debt financing due to the certification effect of the global rating agencies. Employing corporate bonds rated by S\&P, Moody's and/or Fitch in the U.S., Bongaerts, Cremers, and Goetzmann (2012) find that Fitch ratings, which are typically higher than S\&P or Moody's ratings, significantly reduces the cost of debt in the investment grade rating category due to the incremental certification effect by Fitch ratings. Additionally, Li et al. (2006) find that the stock prices of Japanese firms react more strongly to rating downgrades by global rating agencies than by local rating agencies, suggesting that global rating agencies have a greater reputation than the local rating agencies in Japan.

However, in the international capital markets area, there are not that many studies about the relationship between the reputation of rating agencies and corporate bond yields. Han et al. (2012), found that bonds rated by at least one global agency are associated with a significant reduction in the cost of debt compared to those rated by only Japanese rating agencies. They also find that non-financial Japanese firms with poor financial quality and greater information asymmetry are more likely to acquire ratings from Moody's or S\&P rather than local rating agencies. It seems that these non-financial firms in Japan obtain ratings from global raters to reduce the cost of debt by relying on their stronger reputation. Except for Han et al. (2012), there have been no studies that demonstrate why local firms hire global rating agencies despite lower ratings, or whether the cost of debt is reduced when ratings are obtained from global rating agencies. Consequently, our study examines if Japanese financial firms pay lower costs of debt when they hire global rating agencies to issue bonds. This current research investigates the association between the influence of global rating agencies and the cost of debt in a foreign country.

\section{Hypotheses and Research Methods}

According to the previous research (Li et al., 2006; Han et al., 2012), global rating agencies are considered more influential than local ones. Hence, financial firms rated by Moody's or S\&P are expected to pay lower costs of debt than those rated by only local raters. Hence, our first hypothesis is as follows.
Hypothesis 1: The yield spreads of financial firms rated by only local agencies are higher than those by global agencies.

To test hypothesis 1, the yield spreads of new bonds between firms rated by global raters and those by Japanese agencies will be compared with mean tests. To compute the yield spreads, Japanese government bond yields will be subtracted from corporate bond yields with comparable maturities to control for the term structure of interest rates. Second, implementing Fabozzi (2007) ${ }^{\text {vi }}$ who states that credit ratings and maturity affect yield spreads between Treasury and non-Treasury securities, the following linear regression model [Equation (1)] is used to re-examine findings in the mean tests.

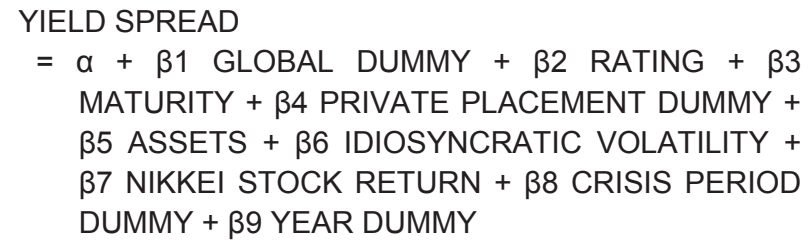

In Equation (1), the definition of each variable is as follows and the expected sign of each coefficient is provided in parentheses:

Yield Spreads: yield spread between new corporate bond and comparable maturity Japanese government bond;

Global Dummy: a dummy variable equal to one if a bond is rated by at least one global agency and zero if a bond is rated by only local agencies. If the coefficient of the Global Dummy variable is negative and significant, we can conclude that a bond rated by at least one global rater pays a lower interest rate than a bond rated by only Japanese rating agencies (-);

Rating: numerical ranking of bond rating (-); ${ }^{\text {vii }}$

Maturity: log of bond maturity, in years (+);

Private Placement Dummy: dummy variable equal to one if a bond is issued by private placement and zero otherwise $(-)$ : $^{\text {iii }}$

Total Assets: log of total assets of the bond issuer (-);ix

Idiosyncratic Volatility: idiosyncratic risk of the issuer estimated from the standard errors of a market model $(+) ;^{X}$

Nikkei Stock Return: daily raw return of the Nikkei Stock Market Index in Japan on the issue date $(+){ }^{x i}$

Crisis Period Dummy: dummy variable equal to one if the bond is issued on or between 4/24/2007 and 3/31/2009 and zero otherwise $(+){ }^{x i i}$

Year Dummies: to control for time effects, year dummy variables are included for bonds issued during each calendar year. xiii $^{\text {inc }}$ 
Unlike Han et al. (2012), we do not test the interaction term between the global dummy variable and crisis period dummy variable because the interaction term cannot be specified due to too few observations over the financial crisis period. Our sample is a panel data set that consists of new debt issued from 1998 to 2014 with cross-sectional variables across different years. As a result, it is important to control for time-specific effects. Year dummy variables are employed to control for time-specific effects.

Han et al. (2012) report that Japanese non-financial firms with weak financial quality and greater asymmetric information are more likely to obtain ratings from global agencies to reduce the cost of debt by depending on the better reputation of the global raters. Therefore, we have the following second hypothesis.

Hypothesis 2: Japanese financial firms with weak financial quality and greater asymmetric information are more likely to obtain ratings from global agencies.

To examine Hypothesis 2, the following probit model [Equation (2)] is employed. The definition of each variable is provided below. The expected sign of each coefficient is presented in parentheses.

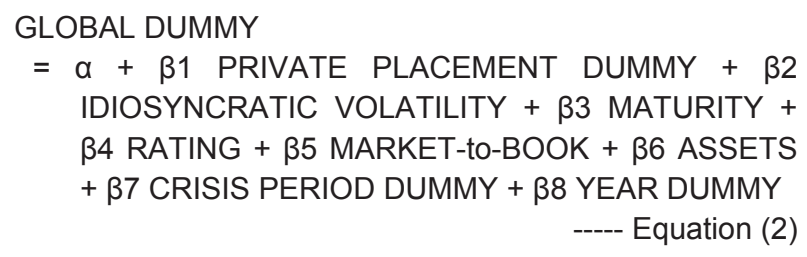

Global Dummy: a dummy variable equal to one if the bond is rated by at least one global agency and zero if the bond is rated by only local agencies; ${ }^{\text {xiv }}$

Private Placement Dummy: dummy variable equal to one if the bond is issued by private placement and zero otherwise $(+)$;

Idiosyncratic Volatility: idiosyncratic risk of the issuer estimated from the standard errors of a market model $(+)$;

Maturity: log of bond maturity, in years $(+){ }^{x v}$

Rating: numerical ranking of bond rating (-);

Market-to-Book: market value of equity / book value of equity (+);

Total Assets: Natural Log of Total Assets (-);

Crisis Period Dummy: dummy variable equal to one if the bond is issued between or on 4/24/2007 and 3/31/2009 and zero otherwise $(+)$.

The rating variable represents the issuer's financial quality, and the private placement dummy, idiosyncratic volatility, and total assets indicate asymmetric information. Firms choosing private placement are generally smaller and have more opaque assets (Carey, Rea, Prowse, \& Udell, 1993) than those adopting public offerings. In addition, it is likely that firms with a greater market-to-book ratio have higher growth potential in the future and depend on global raters. Livingston, Naranjo, and Zhou (2007) use total assets and percentage of fixed assets to measure assets opaqueness. Furthermore, given prior research, we assume that firms are more likely to seek out global ratings over the financial crisis period and benefit from their reputation.

Morgan (2002) contends that the split ratings of banks between S\&P and Moody's in the U.S. result from poor information dissemination by bond issuers. Morgan (2002) argues that bank assets are more opaque, meaning that it is difficult to obtain and evaluate information. Morgan's research based on banks suggests that split ratings occur when two rating agencies struggle to deal with poor data and come to different conclusions. Ordered probit models (Ederington, 1986; Morgan, 2002; Shin \& Moore, 2003) are applied to examine whether both global and local raters consider asymmetric nature of financial firms in their credit ratings. The dependent variable is the numerical average of the credit ratings for each bond issue. We compare the rating methodology of each agency using the ordered probit models. According to Fabozzi (2016), ${ }^{\text {xvi }}$ rating agencies assess financial and business risk when they assign credit ratings. The profitability, debt, and operating efficiency ratios are used to measure a firm's financial risk. Total assets are used to indicate business risk because we assume firms with larger total assets can generate more revenue and market share. We also employ idiosyncratic volatility to measure asymmetric information. Our third hypothesis is as follows.

Hypothesis 3: Both global and local rating agencies incorporate asymmetric information into their credit ratings for financial firms.

To examine Hypothesis 3, the following ordered probit model is employed.

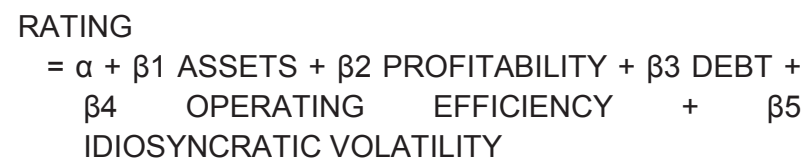

----- Equation (3)

The rating variable is the dependent variable. Independent variables, which could be the determinants of credit ratings, are defined as shown below. The expected sign of each coefficient is presented in parentheses.

Rating: numerical ranking of bond rating; 
Total Assets: Natural Log of Total Assets (+);

Profitability: EBIT (Earnings Before Interest and Taxes) / Total Revenue (+);

Total Debt: Total Debt / Total Assets (-);

Operating Efficiency: Total Revenue / Total Assets (+);

Idiosyncratic Volatility: idiosyncratic risk of the issuer estimated from the standard errors of a market model (-).

There could be a sample selection bias when the second hypothesis is tested. We adopt Heckman (1979)'s method to investigate possible selection bias. Following Poon (2003) and Han et al. (2012), we first estimate the Inverse Mills Ratio (IMR) from Equation (2), add it to Equation (3), and then determine whether the coefficient of the IMR variable is significant. If the coefficient is significant, we believe that there is evidence of sample selection bias in our research.

\section{Data and Descriptive Statistics}

The data consists of corporate bonds issued by 113 Japanese financial firms such as commercial banks, insurance companies, investment banks rated by R\&I, JCR, Moody's and/or S\&P from 1998 to 2014. Only Japanese firms are chosen because it is very difficult to obtain bond yield data for financial firms rated by both global and local rating agencies in a foreign country. The long-term issuer of the credit ratings are obtained from Bloomberg. ${ }^{\text {xii }}$ The corporate and Japanese government bond yields are obtainable from NEEDS-Financial QUEST database provided by Nikkei Media Marketing, Inc. Only long-term straight corporate bonds with more than one-year of maturity are included. Financial variables such as total assets, EBIT, total revenue, and total debt also come from the NEEDS database.

Table 1 presents the descriptive statistics of new bonds assigned by each rating agency in Japan. Out of 1,050 new yen-denominated bonds issued from 1998 to 2014, 477 bonds $(45.43 \%)$ are rated by only Japanese rating agencies: 176 bonds (16.76\%) are rated by $R \& I$ alone, 168 bonds (16\%) are rated by only JCR, and both R\&I and JCR rated 133 bonds (12.67\%). The rest of the bonds, 573 bonds $(54.57 \%)$, are rated by at least one global rater. Of the 573 bonds only $18(3.14 \%)$ are solely rated by S\&P and/or Moody's, the rest were also rated by local rating agencies. For instance, 185 bonds (17.62\%) are evaluated by all four rating agencies, followed by 155 bonds (14.76\%) by a combination of R\&I, JCR, and S\&P. 238 bonds (22.67\%) have S\&P's ratings in addition to R\&I or JCR ratings, while only 45 bonds (4.29\%) add Moody's ratings to local agency ratings.
Table 1: Descriptive Statistics of New Bonds Assigned by Rating Agencies

\begin{tabular}{|l|c|c|}
\hline \multicolumn{1}{|c|}{ Rating Agency } & N & Percent \\
\hline R\&I & 176 & 16.76 \\
\hline JCR & 168 & 16.00 \\
\hline S\&P & 3 & 0.29 \\
\hline Moody's & 3 & 0.29 \\
\hline R\&I and JCR & 133 & 12.67 \\
\hline S\&P and Moody's & 12 & 1.14 \\
\hline R\&I and S\&P & 79 & 7.52 \\
\hline R\&I and Moody's & 27 & 2.57 \\
\hline JCR and S\&P & 4 & 0.38 \\
\hline JCR and Moody's & 2 & 0.19 \\
\hline R\&I, JCR, and S\&P & 155 & 14.76 \\
\hline R\&I, JCR, and Moody's & 16 & 1.52 \\
\hline S\&P, Moody's, and R\&I & 79 & 7.52 \\
\hline S\&P, Moody's, and JCR & 8 & 0.76 \\
\hline R\&I, JCR, S\&P, and Moody's & 185 & 17.62 \\
\hline Total & 1050 & 100 \\
\hline
\end{tabular}

Note: All sample bonds are issued by financial firms from 1998 to 2014. All long-term issuer credit ratings are acquired from Bloomberg. $\mathrm{N}$ is the number of new bonds.

Additionally, only 6 bonds $(0.6 \%)$ obtain ratings exclusively from either S\&P or Moody's. Unlike non-financial firms in the study of Han et al. (2012), most Japanese financial firms prefer S\&P's ratings to Moody's ratings when they add a global rating agency. However, consistent with Han et al. (2012), we confirm that the majority of Japanese financial firms hire not only Japanese raters but also at least one global rating agency.

Table 2: Distribution of New Bonds by Rating Category and Rating Agency

\begin{tabular}{|l|c|c|c|c|c|}
\hline Letter Ratings & $\begin{array}{c}\text { Numerical } \\
\text { Ratings }\end{array}$ & $\mathbf{R} \& \mathbf{l}$ & JCR & S\&P & Moody's \\
\hline AAA (Aaa) & 16 & 4 & 7 & 0 & 0 \\
\hline AA+ (Aa1) & 15 & 0 & 21 & 0 & 0 \\
\hline AA (Aa2) & 14 & 40 & 38 & 1 & 2 \\
\hline AA- (Aa3) & 13 & 136 & 204 & 13 & 5 \\
\hline A+ (A1) & 12 & 219 & 89 & 27 & 10 \\
\hline A (A2) & 11 & 217 & 156 & 48 & 43 \\
\hline A- (A3) & 10 & 163 & 63 & 178 & 97 \\
\hline BBB+ (Baa1) & 9 & 29 & 36 & 176 & 40 \\
\hline BBB (Baa2) & 8 & 33 & 24 & 59 & 80 \\
\hline BBB- (Baa3) & 7 & 8 & 28 & 2 & 51 \\
\hline BB+ (Ba1) & 6 & 0 & 4 & 11 & 1 \\
\hline BB (Ba2) & 5 & 0 & 0 & 1 & 0 \\
\hline BB- (Ba3) & 4 & 0 & 0 & 0 & 3 \\
\hline B+ (B1) & 3 & 0 & 0 & 9 & 0 \\
\hline B (B2) & 2 & 0 & 0 & 0 & 0 \\
\hline B- (B3) & 1 & 0 & 0 & 0 & 0 \\
\hline Below B- (B3) & 0 & 1 & 1 & 0 & 0 \\
\hline Total & & 850 & 671 & 525 & 332 \\
\hline
\end{tabular}


Note: All sample bonds are issued by financial firms from 1998 to 2014. All long-term issuer credit ratings are acquired from Bloomberg. The first letter rating symbols are used by R\&l, JCR, and S\&P, and the second letter rating symbols by Moody's. $\mathrm{N}$ is the number of new bonds.

Table 2 presents the distribution of new bonds by rating category and rating agency. While R\&I assigns speculative grade ratings to only one bond and JCR 5 bonds, S\&P provides speculative ratings to 21 bonds and Moody's 4 bonds. Plus, even though the majority of the new bonds have investment grade ratings, local raters assign a slightly larger proportion of investment grade ratings than global rating agencies. For instance, out of investment grade ratings, local agencies assign 11 bonds to AAA ratings, but global counterparts provide zero AAA-rated bonds. We confirm the results of Han et al. (2012) that Moody's and S\&P are more conservative in their credit risk assessment.

Table 3 shows the mean ratings across different rating agencies in Panel $A$ and the mean test results in Panel $B{ }^{\text {xviii }}$ The letter ratings were converted to numeric ratings as described in Table 2. According to Panel A, JCR assigns the highest mean (11.57) rating, while Moody's the lowest mean (9.13) rating over the entire sample period. We also find that global raters present lower mean ratings than local agencies in the entire period. The same pattern is found in the crisis period. In addition, Panel A shows that mean ratings in the crisis period are higher than those during the entire period for each rating agency, e.g., JCR went from 11.57 to 12.21 . This may imply that riskier financial firms issued less debt during the crisis period.

According to the two-sample mean (t-test) test results, shown in Panel B, between various pairs of rating agencies over the entire period and the crisis period, the mean ratings of local raters are significantly higher than those of global raters at the $1 \%$ significance level. For instance, the $t$ statistic for mean differences between R\&I and Moody's ratings is 21.87 over the entire period. This means R\&I ratings are about 2 ratings higher than Moody's at the $1 \%$ significance level. The mean rating difference between JCR and Moody's is 2.44 , which is also significantly different at the $1 \%$ level $(t=19.46)$ in the entire period. Additionally, we report that the mean $R \& I$ ratings are significantly lower than JCR ratings ( $t=-2.79)$ and that S\&P's ratings are significantly higher than Moody's ratings $(t=3.31)$ at the $1 \%$ level over the entire period. In contrast, when it comes to the crisis period, the mean rating differences between local rating agencies do not exist anymore, and the same is true for the two global rating agencies. This last finding may reflect a more conservative approach by the rating agencies over the crisis period, combined with riskier financial firms issuing less debt during the crisis period.
Table 3: Comparison of Ratings between Rating Agencies Panel A. Mean Ratings

\begin{tabular}{|c|c|c|c|c|}
\hline & \multicolumn{2}{|c|}{ Entire Period } & \multicolumn{2}{c|}{ Crisis Period } \\
\hline Agency & $\mathrm{N}$ & Mean & $\mathrm{N}$ & Mean \\
\hline R\&I & 850 & 11.32 & 86 & 11.97 \\
\hline JCR & 671 & 11.57 & 80 & 12.21 \\
\hline S\&P & 525 & 9.49 & 69 & 10.23 \\
\hline Moody's & 332 & 9.13 & 27 & 9.89 \\
\hline
\end{tabular}

Panel B. Two-Sample Mean Tests of Ratings

\begin{tabular}{|c|c|c|c|c|}
\hline Agency & \multicolumn{2}{|c|}{ Entire Period } & \multicolumn{2}{|c|}{ Crisis Period } \\
\hline $\begin{array}{c}\text { R\&I vs. } \\
\text { JCR }\end{array}$ & $\begin{array}{c}\text { Mean } \\
\text { Difference }\end{array}$ & -0.25 & $\begin{array}{c}\text { Mean } \\
\text { Difference }\end{array}$ & -0.25 \\
\hline & t-value & $(-2.79)^{\star * *}$ & t-value & $(-1.12)$ \\
\hline $\begin{array}{l}\text { S\&P vs. } \\
\text { Moody's }\end{array}$ & $\begin{array}{c}\text { Mean } \\
\text { Difference }\end{array}$ & 0.36 & $\begin{array}{c}\text { Mean } \\
\text { Difference }\end{array}$ & 0.34 \\
\hline & t-value & $(3.31)^{\star * *}$ & t-value & $(1.23)$ \\
\hline $\begin{array}{c}\text { R\&I vs. } \\
\text { S\&P }\end{array}$ & $\begin{array}{c}\text { Mean } \\
\text { Difference }\end{array}$ & 1.82 & $\begin{array}{c}\text { Mean } \\
\text { Difference }\end{array}$ & 1.73 \\
\hline & t-value & $(21.56)^{\star \star *}$ & t-value & $(9.91)^{\star * *}$ \\
\hline $\begin{array}{l}\text { R\&I vs. } \\
\text { Moody's }\end{array}$ & $\begin{array}{c}\text { Mean } \\
\text { Difference }\end{array}$ & 2.19 & $\begin{array}{c}\text { Mean } \\
\text { Difference }\end{array}$ & 2.08 \\
\hline & t-value & $(21.87)^{\star \star \star}$ & t-value & $(8.52)^{\star * *}$ \\
\hline $\begin{array}{c}\text { JCR vs. } \\
\text { S\&P }\end{array}$ & $\begin{array}{c}\text { Mean } \\
\text { Difference }\end{array}$ & 2.07 & $\begin{array}{c}\text { Mean } \\
\text { Difference }\end{array}$ & 1.98 \\
\hline & t-value & $(19.81)^{\star * *}$ & t-value & $(7.95)^{* * *}$ \\
\hline $\begin{array}{l}\text { JCR vs. } \\
\text { Moody's }\end{array}$ & $\begin{array}{c}\text { Mean } \\
\text { Difference }\end{array}$ & 2.44 & $\begin{array}{c}\text { Mean } \\
\text { Difference }\end{array}$ & 2.32 \\
\hline & t-value & $(19.46)^{\star \star \star}$ & t-value & $(6.24)^{\star \star *}$ \\
\hline
\end{tabular}

Note: The letter ratings are converted into numeric ratings. The ratings are defined as: $A A A(A a a)=16, A A+(A a 1)=15, A A$ $(\mathrm{Aa} 2)=14, \mathrm{~A} A-(\mathrm{Aa} 3)=13, \mathrm{~A}+(\mathrm{A} 1)=12, \mathrm{~A}(\mathrm{~A} 2)=11, \mathrm{~A}-(\mathrm{A} 3)=10$, $B B B+(B a a 1)=9$, and etc. $N$ is the number of rated new bonds. t-tests are used for the mean tests. The crisis period refers to the periods of global financial crisis from 4/24/2007 to $3 / 31 / 2009$. $* * *$ denotes significance at the $1 \%$ level.

\section{Empirical Results}

Table 4 presents the comparison of yield spreads between rating agencies. Panel $A$ shows the mean yield spreads over the entire period and crisis period, and Panel $B$ t-test results for mean yield spread differences between various pairs of rating agencies. In Panel $A$, while bonds rated by $R \& I$ have the lowest mean yield spread $(51.22$ basis points (bps)), those by Moody's have the highest mean yield spread (59.50 basis points) over the entire period. 
Table 4: Comparison of Yield Spreads between Rating Agencies Panel A. Mean Yield Spreads

\begin{tabular}{|c|c|c|c|c|}
\hline & \multicolumn{2}{|c|}{ Entire Period } & \multicolumn{2}{c|}{ Crisis Period } \\
\hline Agency & $\mathrm{N}$ & Mean & $\mathrm{N}$ & Mean \\
\hline R\&I & 850 & 51.22 & 86 & 49.34 \\
\hline JCR & 671 & 59.26 & 80 & 55.63 \\
\hline S\&P & 525 & 53.30 & 69 & 53.72 \\
\hline Moody's & 332 & 59.50 & 27 & 80.54 \\
\hline Global & 573 & 51.80 & 69 & 53.72 \\
\hline Local & 477 & 56.91 & 32 & 54.72 \\
\hline
\end{tabular}

Panel B. Two-Sample Mean Tests of Yield Spreads

\begin{tabular}{|c|c|c|c|c|}
\hline Agency & \multicolumn{2}{|c|}{ Entire Period } & \multicolumn{2}{|c|}{ Crisis Period } \\
\hline R\&I vs. JCR & $\begin{array}{c}\text { Mean } \\
\text { Difference }\end{array}$ & -8.05 & $\begin{array}{c}\text { Mean } \\
\text { Difference }\end{array}$ & -6.29 \\
\hline & t-value & $(-2.14)^{\star \star}$ & t-value & $(-0.48)$ \\
\hline $\begin{array}{l}\text { S\&P vs. } \\
\text { Moody's }\end{array}$ & $\begin{array}{c}\text { Mean } \\
\text { Difference }\end{array}$ & -6.20 & $\begin{array}{c}\text { Mean } \\
\text { Difference }\end{array}$ & -26.83 \\
\hline & t-value & $(-1.22)$ & t-value & $(-1.32)$ \\
\hline R\&I vs. S\&P & $\begin{array}{c}\text { Mean } \\
\text { Difference }\end{array}$ & -2.08 & $\begin{array}{c}\text { Mean } \\
\text { Difference }\end{array}$ & -4.38 \\
\hline & t-value & $(-0.53)$ & t-value & $(-0.32)$ \\
\hline $\begin{array}{l}\text { R\&I vs. } \\
\text { Moody's }\end{array}$ & $\begin{array}{c}\text { Mean } \\
\text { Difference }\end{array}$ & -8.29 & $\begin{array}{c}\text { Mean } \\
\text { Difference }\end{array}$ & -31.21 \\
\hline & t-value & $(-1.78)^{*}$ & t-value & $(-1.66)$ \\
\hline JCR vs. S\&P & $\begin{array}{c}\text { Mean } \\
\text { Difference }\end{array}$ & 5.96 & $\begin{array}{c}\text { Mean } \\
\text { Difference }\end{array}$ & 1.91 \\
\hline & t-value & $(1.39)$ & t-value & $(0.13)$ \\
\hline $\begin{array}{l}\text { JCR vs. } \\
\text { Moody's }\end{array}$ & $\begin{array}{c}\text { Mean } \\
\text { Difference }\end{array}$ & -0.24 & $\begin{array}{c}\text { Mean } \\
\text { Difference }\end{array}$ & -24.92 \\
\hline & t-value & $(-0.05)$ & t-value & $(-1.29)$ \\
\hline $\begin{array}{c}\text { Global vs. } \\
\text { Local }\end{array}$ & $\begin{array}{c}\text { Mean } \\
\text { Difference }\end{array}$ & -5.11 & $\begin{array}{c}\text { Mean } \\
\text { Difference }\end{array}$ & -1.01 \\
\hline & t-value & $(-1.15)$ & t-value & $(-0.06)$ \\
\hline
\end{tabular}

Note: To compute the yield spreads, Japanese government bond yields are subtracted from corporate bond yields with comparable maturities to control the term structure of interest rates. $\mathrm{N}$ is the number of rated bonds. "Local" means that bonds are rated by only Japanese agencies, while "Global" indicates that bonds are rated by at least one global agency. t-tests are used for the mean tests. The crisis period refers to the periods of global financial crisis from $4 / 24 / 2007$ to $3 / 31 / 2009$. ** denotes significance at the $5 \%$ level, and * indicates significance at the $10 \%$ level.

The finding that R\&l has the lowest yield spread, and Moody's the highest yield spread does not change in the crisis period. However, when we look at the mean yield spreads of global versus local agencies, global raters have lower mean yield spreads than local agencies during the entire period (51.80 bps versus $56.91 \mathrm{bps}$ ) and also during the crisis period ( 53.72 bps versus $54.72 \mathrm{bps}$ ).

Panel B provides the mean test results of the yield spreads of the bonds rated by different pairs of rating agencies for the full sample and the crisis periods. In general, we find no significant mean yield differences between global and local raters during the entire and crisis periods. Even though the yield spreads of the bonds rated by R\&I are slightly lower than those by JCR or Moody's at the $5 \%$ significance level $(t=-2.14)$ or $10 \%$ level $(t=-1.78)$, respectively, over the entire sample period, there are no significant mean differences of the yield spreads between any pair of rating agencies regardless of the sample period. These results are contradictory to those by Han et al. (2012), where local Japanese raters were found to have significantly higher mean yield spreads than global raters for nonfinancial firms during their entire sample period.

Table 5 reports the test results of mean differences in firm characteristics between firms with global ratings and those with only local ratings. We find that Japanese financial firms with less asymmetric information and greater growth potential seek ratings from global rating agencies. For instance, firms with global ratings have significantly lower idiosyncratic risk ( $\mathrm{t}=-3.75)$ and larger total assets $(\mathrm{t}=7.46)$ than firms with only local ratings at the $1 \%$ level. Additionally, firms rated by S\&P or Moody's have greater market-to-book ratios than those by R\&I or JCR at the $1 \%$ significance level $(t=3.73)$. It is surprising that firm quality does not affect the choice of rating agencies because there are no significant differences in profitability, leverage, and operating efficiency between firms using global raters and those who choose only local rating agencies. According to Han et al. (2012), Japanese non-financial firms with poor financial profiles seek ratings from Moody's or S\&P, which differs from our findings.

Table 5: Mean Test Results for the Comparison of Firm Characteristics

\begin{tabular}{|c|c|c|c|}
\hline & $\mathbf{N}$ & Mean & t-statistics \\
\hline Idiosyncratic Risk & & & \\
\hline Global & 536 & 0.0005148 & $(-3.75)^{\star * *}$ \\
\hline Local & 443 & 0.0006125 & \\
\hline Total Assets & & & \\
\hline Global & 380 & $1.17 \mathrm{E}+10$ & $(7.46)^{* * *}$ \\
\hline Local & 376 & $3.29 \mathrm{E}+09$ & \\
\hline Market-to-Book Ratio & & & $(3.73)^{\star * *}$ \\
\hline Global & 377 & 1.6295 & \\
\hline Local & 368 & 1.1944 & $(1.16)$ \\
\hline Profitability & & & \\
\hline Global & 375 & 0.2021 & $(0.14)$ \\
\hline Local & 375 & 0.1781 & \\
\hline Total Debt & & & \\
\hline Global & 380 & 0.4186 & $(0.01)$ \\
\hline Local & 376 & 0.4154 & \\
\hline Operating Efficiency & & & \\
\hline Global & 380 & 0.138 & \\
\hline Local & 376 & 0.138 & \\
\hline
\end{tabular}

Note: All firm characteristics data are acquired from the NEEDS database. $\mathrm{N}$ is the number of rated bonds. t-tests are used for 
the mean tests. $* * *$ denotes significance at the $1 \%$ level. The definition of each variable is as follows: Total Assets, Marketto-Book: market value of equity / book value of equity, Profitability: EBIT (Earnings Before Interest and Taxes) / Total Revenue, Total Debt: Total Debt / Total Assets, Operating Efficiency: Total Revenue / Total Assets, Idiosyncratic Volatility: idiosyncratic risk of the issuer estimated from the standard errors of market model. "Local" means that bonds are rated by only Japanese agencies, while "Global" indicates that bonds are rated by at least one global agency.

Table 6 reports the results of two multivariate tests suggested by Equation (1). Model 1 is the fixed effects model controlling for time-specific effects and Model 2 fixed effects model adjusting the standard errors for time clustering. ${ }^{\text {xix }}$ The dependent variable is the yield spread. In Models 1 and 2, none of the global dummy variables are significant at any level. Additionally, the crisis period dummy variable is also not significant in either model. In Model 1 , the coefficients of the rating, maturity, private placement dummy, and idiosyncratic volatility variables are significant at the $1 \%$ level, and the sign of each coefficient is consistent with our expectations. For example, the coefficient of the rating variable is negative and significant at the $1 \%$ level $(\mathrm{t}=$ -11.67) implying that bonds with higher ratings are issued at lower yields.

Table 6: Empirical Results of Linear Regression Models for the Yield Spread

\begin{tabular}{|c|c|c|}
\hline Variable & Model 1 & Model 2 \\
\hline Global Dummy & $-2.17(-0.43)$ & $-7.28(-0.90)$ \\
\hline Rating & $-20.56(-11.67)^{\star * *}$ & $-15.63(-2.84)^{* *}$ \\
\hline Log of Maturity & $18.44(3.88)^{* * *}$ & $11.62(1.74)$ \\
\hline Private Placement Dummy & $-48.95(-4.96)^{* * *}$ & $-65.05(-2.87)^{* *}$ \\
\hline Log of Total Assets & $-3.29(-1.61)$ & $-4.39(-2.27)^{* *}$ \\
\hline Idiosyncratic Volatility & $28477.36(3.93)^{\star * *}$ & $30486.43(2.23)^{* *}$ \\
\hline Nikkei Stock Return & $-66.75(-0.37)$ & $-239.97(-1.19)$ \\
\hline Crisis Period Dummy & $0.66(0.04)$ & $4.11(0.56)$ \\
\hline N & 745 & 745 \\
\hline Prob. > F & 0.0000 & 0.0012 \\
\hline Adjusted R-SQ & 0.33 & 0.18 \\
\hline
\end{tabular}

Note: The dependent variable is the yield spread between new corporate bonds and comparable maturity Japanese government bonds. The definitions of independent variables are as follows. Global Dummy: a dummy variable equal to one if a bond is rated by at least one global agency and zero if a bond is rated by only local agencies, Rating: ordered rankings of bond ratings (The letter ratings are converted into numeric ratings. The ratings are defined as: AAA (Aaa) $=16$, $A A+(A a 1)=15, A A(A a 2)=14, A A-(A a 3)=13, A+(A 1)=12, A$ $(A 2)=11, A-(A 3)=10, B B B+(B a a 1)=9$, and etc. If a firm is rated by both global and local raters, we use the average of the credit ratings on the date of new bond issue (Reeb, Mansi, \& Allee, 2001), Maturity: log of maturities of bonds, in years,
Private Placement Dummy: dummy variable equal to one if a bond is issued by private placement and zero otherwise, Total Assets: log of total assets of the bond issuer, Idiosyncratic Volatility: idiosyncratic risk of the issuer estimated from the standard errors of market model (the standard errors based on the market model with 250 days of past stock returns for the firm ending one month prior to the bond issuance are estimated), Nikkei Stock Return: daily raw return of the Nikkei Stock Market Index in Japan on the issue date, Crisis Period Dummy: dummy variable equal to one if a bond is issued from $4 / 24 / 2007$ to $3 / 31 / 2009$ and zero otherwise, Year Dummies: to control for time effects, year dummy variables are included for bonds issued during each calendar year. ${ }^{* * *}$ denotes significance at the $1 \%$ level, and ${ }^{* *}$ indicates significance at the $5 \%$ level. Model 1 is the fixed effects model controlling for time-specific effects and Model 2 fixed effects model adjusting the standard errors for time clustering. $\mathrm{N}$ is the number of rated bonds.

Bonds with greater asymmetric information are sold at higher yields because the coefficient of the idiosyncratic volatility variable is positive and significant at the $1 \%$ level $(\mathrm{t}=3.93)$. Moreover, the coefficient of the private placement dummy variable is negative and significant at the $1 \%$ level $(\mathrm{t}=-4.96)$ implying most bonds issued by private placements are guaranteed by a main bank (Han, Pagano, \& Shin, 2018). ${ }^{x x}$ Model 2 confirms the findings in Model 1, and shows that firms with greater size can issue bonds at lower yields. The coefficient of the total assets variable is negative and significant at the $5 \%$ level $(\mathrm{t}=-2.27)$. In summary, we confirm our findings in Table 4 and conjecture that the reputation effect of global rating agencies does not exist for Japanese financial firms. ${ }^{x \times i}$

In Table 7, a firm's decision to obtain a global credit rating is examined using two different probit models [Equation (2)]. Model 1 has a year dummy variable, but Model 2 does not. ${ }^{\text {xii }}$ In all models, firms with a higher market-to-book ratio and larger total assets are more likely to obtain ratings from global rating agencies. For example, in Model 1, the coefficients of the market-to-book ratio variable and the total assets variable are positive and significant at the $1 \%$ level $(t=3.12$ and $t=7.53$, respectively). Furthermore, it is likely that firms issuing bonds through private placements hire local raters because bonds issued through private placements are generally customized, sold to institutional investors, and are less liquid than public bonds. Additionally, small firms generally adopt private placement. Consistent with the findings in Table 5, financial firms with less information asymmetry and higher growth potential are more likely to obtain ratings from Moody's or S\&P. Additionally, the firm's financial quality does not affect a firm's choice to acquire a global rating because the coefficient of the rating variable is not significant at any level. 
Table 7: Empirical Results of Probit Models of Global Rating Choice

\begin{tabular}{|c|c|c|}
\hline Variable & Model 1 & Model 2 \\
\hline Private Placement Dummy & $-0.94(-3.25)^{\star * *}$ & $-0.66(-3.58)^{\star * *}$ \\
\hline Idiosyncratic Volatility & $7.39(0.04)$ & $133.15(0.93)$ \\
\hline Log of Maturity & $-0.03(-0.25)$ & $0.02(0.11)$ \\
\hline Rating & $0.03(0.74)$ & $-0.01(-0.18)$ \\
\hline Market-to-Book Ratio & $0.15(3.12)^{\star * *}$ & $0.18(2.90)^{\star \star *}$ \\
\hline Log of Total Assets & $0.38(7.53)^{* * *}$ & $0.41(6.76)^{\star * *}$ \\
\hline Crisis Period Dummy & $0.34(0.90)$ & $0.16(1.57)$ \\
\hline $\mathrm{N}$ & 743 & 743 \\
\hline Prob. > Chi-SQ & 0.0000 & 0.0000 \\
\hline Pseudo R-SQ & 0.22 & 0.15 \\
\hline
\end{tabular}

Note: The dependent variable is Global Dummy: a dummy variable equal to one if a bond is rated by at least one global agency and zero if a bond is rated by only local agencies. The definitions of independent variables are as follows. Private Placement Dummy: dummy variable equal to one if a bond is issued by private placement and zero otherwise, Idiosyncratic Volatility: idiosyncratic risk of the issuer estimated from the standard errors of market model, Maturity: log of maturities of bonds, in years, Rating: ordered rankings of bond ratings (The letter ratings are converted into numeric ratings. The ratings are defined as: $A A A(A a a)=16, A A+(A a 1)=15, A A$ $(\mathrm{Aa} 2)=14, \mathrm{AA}-(\mathrm{Aa} 3)=13, \mathrm{~A}+(\mathrm{A} 1)=12, \mathrm{~A}(\mathrm{~A} 2)=11, \mathrm{~A}-(\mathrm{A} 3)=10$, $B B B+(B a a 1)=9$, and etc. $)$ Market-to-Book: market value of equity / book value of equity, Total Assets: Natural Log of Total Assets, Crisis Period Dummy: dummy variable equal to one if a bond is issued from 4/24/2007 to 3/31/2009 and zero otherwise. $* * *$ denotes significance at the $1 \%$ level. Model 1 has year dummy variables, but Model 2 does not. $\mathrm{N}$ is the number of rated bonds.

\section{Robustness Checks}

Because financial firms with less information asymmetry and higher growth potential are more likely to obtain ratings from global rating agencies, we use the Heckman (1979) model to determine any selection bias. We first estimate the Inverse Mills Ratio using the decision to obtain global rating equation. Then we include the ratio as an independent variable in the rating determination equation, and evaluate the significance of the coefficient of the Inverse Mills Ratio to check selection bias. We find a significant selection bias because the coefficient of the Inverse Mills Ratio variable is negative and significant at the $1 \%$ level. ${ }^{x x i i i}$ Moreover, following Han et al. (2012), Table 6 is re-estimated by investigating two new global dummy variables, one to control for bonds rated by S\&P and another to control for those rated by Moody's. The results are very similar to those shown in Table 6. The coefficients of the S\&P and Moody's dummies are not significant, and the crisis period dummy variable is not significant. ${ }^{\text {xiv }}$ Hence, our findings in Table 6 are robust even with the inclusion of two separate global dummies. $^{x x v}$

In addition, we wonder why the reputation effect of global rating agencies for non-financial firms discovered by Han et al. (2012) does not exist for financial firms. We conjecture that, because investors recognize the asset opaqueness of financial firms, the asymmetric nature of financial firms offsets the reputation effect of global rating agencies. Using the ordered probit model, Equation (3), we examine the rating methodology of financial firms. Morgan (2002) finds that bank assets are more opaque and banks have greater debt ratio than non-financial firms, and this asset opaqueness and higher leverage ratio result in more split ratings than non-financial firms. We confirm that the absolute rating differences for financial firms in our study are greater than those for non-financial firms in the research of Han et al. (2012). According to Morgan (2002), it is very challenging for investors to determine the cost of debt issued by financial firms due to the uncertainty associated with asymmetric information, and they are less likely to depend on the credit risk assessment by rating agencies. Table 8 tests rating determination equations for each rating agency, and the results show that every rating agency considers asymmetric information in its ratings. For instance, the coefficients of the idiosyncratic volatility variable are negative and significant at the $1 \%$ level, implying that firms with more asymmetric information have more probability to have lower ratings. We also find that larger size firms are more likely to have higher ratings because the coefficients of the total assets variable are generally positive and significant.

Table 8: Empirical Results of Rating Determination Equation for Each Rating Agency

\begin{tabular}{|c|c|c|c|c|}
\hline Variable & R\&l & JCR & S\&P & Moody's \\
\hline Log of Total Assets & $0.23(4.50)^{* * *}$ & $0.89(15.13)^{\star * \star}$ & $-0.19(-2.06)^{\star *}$ & $0.20(1.74)^{*}$ \\
\hline Profitability & $0.47(2.54)^{* *}$ & $0.55(2.62)^{\star * *}$ & $0.46(1.55)$ & $0.13(0.33)$ \\
\hline Total Debt & $-0.74(-2.75)^{\star * *}$ & $0.52(1.49)$ & $-0.87(-1.95)^{*}$ & $2.09(2.07)^{\star *}$ \\
\hline Operating Efficiency & $6.38(8.66)^{\star \star \star}$ & $5.78(5.59)^{\star \star \star}$ & $3.81(3.04)^{\star \star \star}$ & $0.74(0.21)$ \\
\hline Idiosyncratic Volatility & $-1846.68(-11.35)^{* * *}$ & $-497.49(-3.40)^{\star * *}$ & $-2012.11(-8.18)^{\star \star \star}$ & $-1032.44(-3.84)^{\star * *}$ \\
\hline $\mathrm{N}$ & 559 & 476 & 324 & 189 \\
\hline Prob. > Chi-SQ & 0.0000 & 0.0000 & 0.0000 & 0.0000 \\
\hline Pseudo R-SQ & 0.18 & 0.28 & 0.16 & 0.13 \\
\hline
\end{tabular}


Note: This is ordered probit model based on Equation (3). The rating variable is the dependent variable (The letter ratings are converted into numeric ratings. The ratings are defined as: $A A A(A a a)=16, A A+(A a 1)=15, A A(A a 2)=14, A A-(A a 3)=13, A+(A 1)=12, A(A 2)=11, A-$ $(A 3)=10, B B B+(B a a 1)=9$, and etc.). Independent variables, which could be the determinants of credit ratings, are defined as follows. Total Assets: Natural Log of Total Assets, Profitability: EBIT (Earnings Before Interest and Taxes) / Total Revenue, Total Debt: Total Debt / Total Assets, Operating Efficiency: Total Revenue / Total Assets, Idiosyncratic Volatility: idiosyncratic risk of the issuer estimated from the standard errors of market model. $* * *$ denotes significance at the $1 \%$ level, ${ }^{* *}$ indicates significance at the $5 \%$ level, and * significance at the $10 \%$ level. $\mathrm{N}$ is the number of rated bonds.

\section{Conclusion}

We examine the yield spreads of 1,050 new yendenominated corporate bonds issued by financial firms in Japan from 1998 to 2014 and find no evidence that bonds rated by at least one global agency are associated with a significant reduction in the cost of debt compared to those rated by only local Japanese rating agencies. Unlike nonfinancial firms, the reputation effects of global rating agencies do not exist for Japanese financial firms. We also observe that it is more likely for firms with less information asymmetry and higher growth potential to acquire ratings from Moody's or S\&P, and that their financial profile does not affect a firm's choice to seek out ratings from global raters. Our findings are contradictory to those by Han et al. (2012), who employ bonds issued by non-financial firms in Japan from 1998 to 2009. Additionally, we find that the yield spreads of the bonds issued over the 2007-2009 global financial crisis are not significantly different from those in the non-crisis periods.

We analyze why the reputation effect of global rating agencies for non-financial firms discovered by Han et al. (2012) does not exist for financial firms. We test rating determination equations for each rating agency, and the findings show that every rating agency considers asymmetric information in its ratings. Financial firms with more asymmetric information have a higher probability to have lower ratings. We conjecture that the asymmetric nature of financial firms makes investors less likely to depend on the credit risk assessment by rating agencies in determining the yield of new bonds. Future research should be done on foreign currency denominated bonds in Japan to test the reputation effect of rating agencies.

\section{References}

Bolton, P., Xavier, F., \& Shapiro, J. (2012). The credit ratings game. The Journal of Finance, 67, 85-111.

Bongaerts, D., Cremers, M., \& Goetzmann, W. (2012). Tiebreaker: Certification and multiple credit ratings. Journal of Finance, 67, 113-152.
Carey, M., Rea, J., Prowse, S., \& Udell, G. (1993). The economics of private placements: A new look. Financial Markets, Institutions and Instruments, 2(3), 1-67.

Ederington, L. (1986). Why split rating occur. Financial Management, 15(1), 37-47.

Han, S., Pagano, M., \& Shin, Y. (2012). Rating agency reputation, the global financial crisis, and the cost of debt. Financial Management, 41(4), 849-884.

Han, S., Pagano, M., \& Shin, Y. (2018). The evolving nature of Japanese corporate governance: Guaranteed bonds vs. rated bonds. KAIST, Working Paper.

Heckman, J. (1979). Sample selection bias as a specification error. Econometrica, 47(1), 153-161.

Kisgen, D., \& Strahan, P. (2010). Does regulation based on credit ratings affect a firm's cost of capital? The Review of Financial Studies, 23, 4324-4347.

Li, J., Shin, Y., \& Moore, W. T. (2006). Reactions of Japanese markets to changes in credit ratings by global and local agencies. Journal of Banking and Finance, 30, 1007-1021.

Livingston, M., Naranjo, A., \& Zhou, L. (2007). Asset opaqueness and split bond ratings. Financial Management, 36(3), 49-62.

Morgan, D. (2002). Rating banks: Risk and uncertainty in an opaqueness industry. American Economic Review, 92, 874-888.

Okabe, M. (2009). Corporate governance in Japan: Evolution, policy measures, and future issues. Meiji Gakuin University. Retrieved from http://gakkai.sfc.keio.ac.jp/dp_pdf/10-03.pdf

Packer, F., \& Tarashev, N. (2011, June). Rating methodologies for banks. BIS Quarterly Review, 39-52.

Poon, W. (2003). Are unsolicited credit ratings biased downward? Journal of Banking and Finance, 27, 593-614.

Reeb, D., Mansi, S., \& Allee, J. (2001). Firm internationalization and the cost of debt financing: Evidence from non-provisional publicly traded debt. Journal of Financial and Quantitative Analysis, 36(3), 395414.

R\&I. (2017). Rating performance report: Japanese corporate default rates and rating transition matrices (FY1978FY2016). Retrieved from https://www.r-i.co.jp/en/index. html 
Shin, Y., \& Moore, W.T. (2003). Explaining credit rating differences between Japanese and U.S. agencies. Review of Financial Economics, 12(4), 327-344.

Shin, Y., \& Moore, W. T. (2008, Winter). Effects of national recognition on the influence of credit rating agencies: The case of Dominion Bond Rating Service. Financial Decisions, 1-28.
Sufi, A. (2009). The real effects of debt certification: evidence from the introduction of bank loan ratings. Review of Financial Studies, 22, 1659-1691.

Yamori, N., Nishigaki, N., \& Asai, Y. (2006). Credit ratings in the Japanese bond market. Osaka University. Retrieved from http://www.iser.osaka-u.ac.jp/library/dp/2006/ DP0654.pdf

Endnotes:

' Moody's swings, so why are some analysts cautious. (2003, January 6). The Wall Street Journal, p. C1.

ii In this study, we define Moody's and S\&P as global credit rating agencies and Japanese rating agencies, Rating \& Investment Information (R\&l) and Japan Credit Rating Agency (JCR), as local rating agencies.

iii Fabozzi, F. (2007). Fixed Income Analysis (2 ${ }^{\text {nd }}$ ed.). John Wiley \& Sons.

iv According to Packer and Tarashev (2011), rating agencies assign two types of ratings to banks. One is "stand-alone" ratings such as bank financial strength ratings, which reflects only intrinsic financial strength of banks, and the other is "all-in" ratings such as long-term issuer credit ratings, which incorporate government rescue and information asymmetry in addition to financial quality.

${ }^{v}$ R\&I withdrew from the certification in October 2011 without a specific reason. R\&I announced through its website (www.r-i.co.jp) that it was a "business decision."

vi Fabozzi, F. (2007). Fixed Income Analysis ( $2^{\text {nd }}$ ed.). John Wiley \& Sons.

vii The letter ratings are converted into numeric ratings. The ratings are defined as: $A A A(A a a)=16, A A+(A a 1)=15, A A(A a 2)=14, A A-$ $(\mathrm{Aa} 3)=13, \mathrm{~A}+(\mathrm{A} 1)=12, \mathrm{~A}(\mathrm{~A} 2)=11, \mathrm{~A}-(\mathrm{A} 3)=10, \mathrm{BBB}+(\mathrm{Baa} 1)=9$, and etc. If a firm is rated by both global and local raters, we use the average of the credit ratings at the date of new bond issues (Reeb et al., 2001). If R\&l and JCR rate a bond, we also take the average of the ratings.

viii Han, Pagano, and Shin (2018) find that most private placement bonds in Japan are guaranteed by main banks. Hence, we expect negative coefficients for private placement bonds.

ix Bonds issued by bigger firms are considered more liquid and sold at lower yields.

${ }^{x}$ We estimate the standard errors based on the market model with 250 days of past stock returns for the firm ending one month prior to the debt issuance. We use a Japanese-specific market portfolio proxy (Nikkei Stock Index) for each of the firms.

${ }^{\mathrm{xi}}$ We assume that stock market volatility in Japan represents greater uncertainty and possibly heightened risk aversion which can, in turn, increase yield spreads.

xii Following Han et al. (2012), we use this period because The Wall Street Journal first reported problems with the global raters' ratings of subprime debt in "Subprime Cloud Overshadows S\&P, Moody's" on April 24, 2007.

xiii We do not expect any specific signs for Year Dummies.

xiv This is the dependent variable.

${ }^{x v}$ We assume that Japanese firms are more likely to use S\&P or Moody's to sell longer maturity bonds because those bonds have greater interest rate risk.

xvi Fabozzi, F. (2016). Bond Markets, Analysis, and Strategy ( $9^{\text {th }}$ ed.). Pearson.

xvii We do not examine bank financial strength ratings, which have different rating symbols than the long-term issuer credit ratings. According to Packer and Tarashev (2011), bank financial strength ratings reflects the intrinsic financial strength of banks without any external financial support such as government bailout.

xviii The median test results are similar.

xix We also test a model controlling for industry-specific effects and the results do not change. We use year dummies to control for timespecific effects and industry dummies such as commercial banks, investment banks, and insurance companies to control for industry dummies. 
${ }^{x x}$ The coefficients of the year dummy variables are available upon request.

xxi Unlike Han et al. (2012), we do not test the interaction terms between the global dummy and crisis period dummy variables because too few observations are specified. We also do not split the sample into the crisis and pre-crisis periods due to the small number of the bonds issued during the crisis period.

xxii We do not report the coefficients of year dummy variables in Model 1. They are available upon request.

xxiii We do not report the empirical results of the Heckman (1979) model here to save space. They are available upon request.

xxiv We do not report the empirical results with S\&P's and Moody's dummy variables here to save space. They are available upon request.

${ }^{x \times v}$ Our sample also includes 28 bonds with unsolicited ratings by S\&P. Our results are robust after we drop those 28 bonds from the entire sample. Unsolicited ratings are based on public information, and S\&P assigns them without the request of the bond issuers. 